BYRON RANGIWAI

\title{
Representation, COVID-19, and failed metaphor: A critical analysis of the Bay of Plenty District Health Board vaccine booklet
}

\section{Introduction}

This paper will critically analyse the Bay of Plenty District Health Board's (BOPDHB) controversial vaccine booklet, which featured mataora-adorned cartoon images of the COVID-19 virus. This imagery caused a furore with anecdotal evidence from social media suggesting that Māori were outraged by the portrayal of Māori in this way.

This paper will offer two arguments. The first argument builds on Hokowhitu's (2001) work, which deconstructed representations of Māori as animalistic, savage-barbarian, physicalunintelligent, mythical, bewildered-childlike, and romanticised-noble. The first argument will extend Hokowhitu's (2001) analysis by deconstructing the representation of Māori as disease-virus. While it is impossible to understand the BOPDHB's intentions, 
the second argument posits that the objective might have been to use the concept of taniwha as a metaphor for COVID-19. Though this argument is significantly weaker than the first, it still warrants some exploration, even if only to provide a sense of balance to this paper.

This paper will use Hall's (1973) theory of encoding and decoding-which posits that the creator of content encodes it with meaning decoded by the observer-to analyse images from the booklet. While reports have claimed that a Māori artist designed the images and that consultation with Māori had taken place before the release of the booklet (Wilson $\&$ Bathgate, 2021), responsibility for this misrepresentation sits with BOPDHB.

\section{Hall's Theory of Encoding and Decoding}

Hall (1973) offered a theoretical framework to analyse how media communications are generated, distributed, engaged with, and interpreted. Hall's (1973) theory conceives that meaning is encoded into media by the creator. The viewer then decodes. The encoding and decoding of media are based on the cultural and social norms of both the maker and observer. For Hall, culture is a "critical site of social action and intervention, where power relations are both established and potentially unsettled" (Procter, 2004, p. 2).

As a Māori researcher using Hall's theory of encoding and decoding to analyse the BOPDHB's 
vaccine booklet, this analysis will draw on the Māori cultural and social concepts that inform a Māori worldview.

\section{Images of the Bay of Plenty District Health Board} vaccine booklet

The BOPDHB released a COVID-19 vaccine booklet featuring cartoon mataora-adorned images of the COVID-19 virus. Because of the mataora designs, the virus is portrayed as Māori. The BOPDHB immediately withdrew the booklet as it generated backlash among Māori.

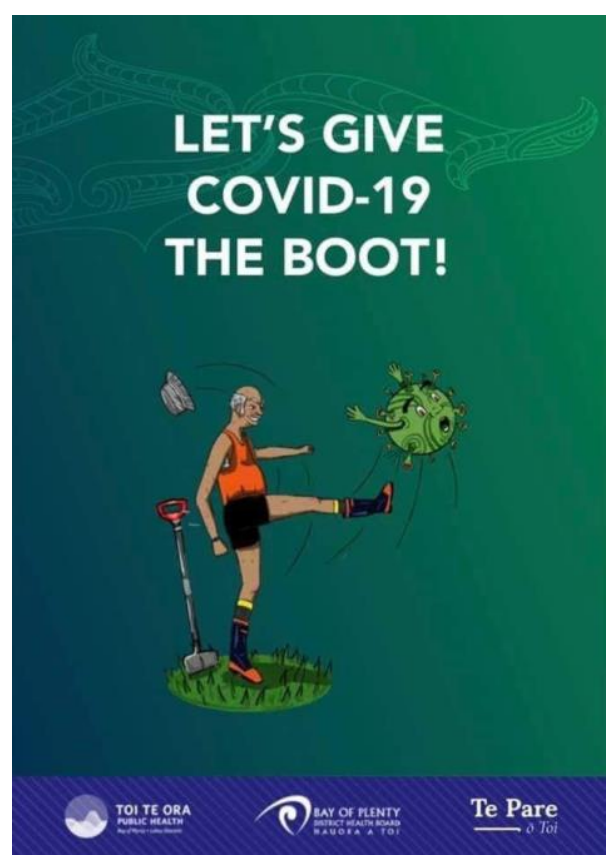

Figure 1. A figure kicks the mataora-adorned virus 


\section{CAN I GET A VACCINE IF I'M PREGNANT?}

You should discuss your individual situation (particularly if you have other medical conditions) and the benefits and risks of receiving the COVID-19 vaccine while pregnant with your midwife or doctor. If you are pregnant and choose to have the vaccine, you can get early access. This is because people who are pregnant can become very sick if they get COVID-19.

\section{CAN I GET A VACCINE IF I'M BREASTFEEDING?}

As with all vaccines on the Aotearoa Immunisation Schedule, there are no safety concerns about giving the Pfizer COVID-19 vaccine to women who are breastfeeding. By being vaccinated, mothers can also provide some protection against COVID-19 for their babies via their breastmilk.

\section{CAN I ATTEND EVENTS (E.G. WHĀNAU GATHERINGS, HUI, TANGIHANGA) ONCE I'VE HAD MY VACCINATION?}

Yes. You're fine to attend any large events dependent on national COVID-19 alert levels.

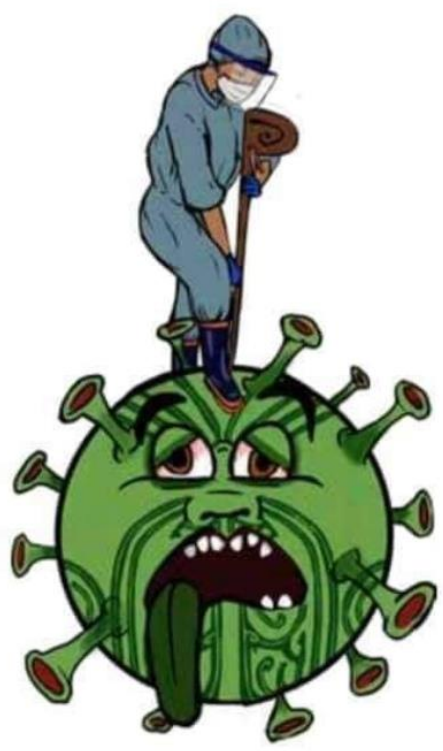

Figure 2. A medical figure stands on and stabs the mataora-adorned virus in the head with what appears to be a tewhatewha 


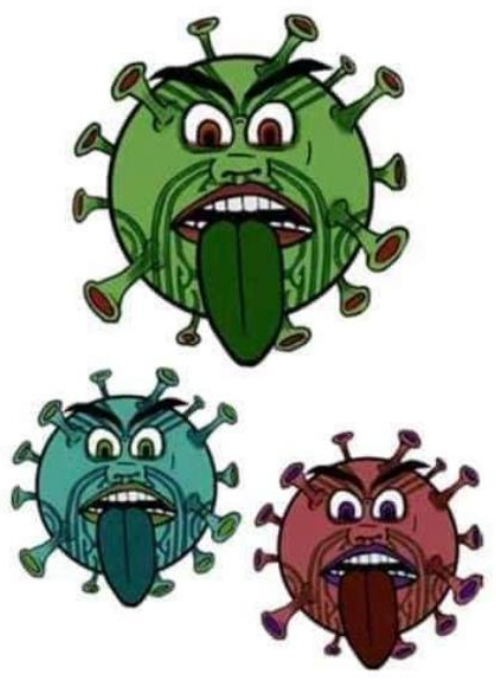

This booklet will provide you with key information regarding your COVID-19 Pfizer vaccination.

Information contained in this booklet is in addition to what you will receive from the Ministry of Health.

Figure 3. Three mataora-adorned virus figures performing the pūkana with tongues extended

\section{Representations of Māori as Other}

When Pākehā arrived in Aotearoa, they came to discover, name, and tame the Pacific by "scientific exploration, evangelism, and colonization" (Salmond, 1985, p. 225). Since Pākehā understood their worldview to be superior, their oppression of Māori was, to them, both legitimate and necessary 
(Smith, 2021). Māori were constructed as inferior to Pākehā within a racialised context justified by Judeo-Christian thinking and biological determinism (Rangiwai, 2010, 2011). Indeed, according to Salmond (1985), evolutionist theories as well as political and economic interests, impacted historical understandings of Māori.

Māori were racially stereotyped in order to justify colonial acts like land seizure (Rangiwai 2010, 2011). These representations - constructed on the "dualisms of savage and civilised, heathen and Christian, immoral and moral"-positioned Māori in contrast to Pākehā in debasing ways (Smith 1997, 33). Māori were thought to require colonisation for "spiritual and economic salvation" (Petrie 1998, 9). The role of the coloniser, therefore, was "to conquer the world," "civilise it," and assimilate the native Other (Hall, 2013; Hokowhitu, 2003, p. 28, 2004; McClintock, 1995).

Hokowhitu (2001) analysed the discourse surrounding the concept of Māori as Other and asserted that the "dominant Pākeha lens of description constructed and then reconstructed an image of Māori that constrained and limited Māori culturally, educationally and economically" (p. 42). Hokowhitu (2001) described the Māori Other through six themes. Māori as: animalistic, savagebarbarian, physical-unintelligent, mythical, bewildered-childlike, and romanticised-noble (Hokowhitu, 2001). 
Mãori as animalistic Other

Māori were perceived and labelled as animal-like, ferocious, and savage in the nineteenth century (Hokowhitu, 2001 2003, 2004). Identifying Māori, as well as other Indigenous peoples as "not fully human, or not human at all, enabled distance to be maintained and justified various policies of either extermination or domestication" (Smith, 2021, p. 29).

These beliefs were paralleled in colonial literature, which constructed a sexualised, animal-like, mythic, prehistoric representation of the Māori savage (Hokowhitu, 2001, 2003, 2004; McNaughton, 2004; Nicole, 2001; Wall, 1997). For example, in colonial children's literature, Māori were portrayed as "wild, beast-like people, far removed from the mother country" as a method of bolstering the colonial enterprise (McNaughton, 2004, pp. 1819). The way Māori were depicted- as "half human, half beast" (Giddens, 1993, p. 30), physically agile "as readily as monkeys" (Wade, 1977, p. 157), and primate-like (Wakefield, 1845 cited in Best, 1925)not only justified colonialism, but also desensitised settlers to colonial violence (Hokowhitu, 2001).

\section{Māori as Savage-Barbarian Other}

Māori were portrayed as barbarians, savages, and inferior to Pākehā (Hokowhitu, 2001). The savagebarbarian Other was an essential part of the 
coloniser/colonised duality, an "allegorical figure that represents what the civilised Self is not" (Hokowhitu, 2003, p. 21). Māori were seen as immoral in the eyes of Christianity, needing to be rescued from heathenism, violence, and barbarism (Smith, 2021). From this viewpoint, then, "the haka was particularly damning as accounts of its ferocity were interpreted through the white gaze" (Rangiwai, 2012 , p. 58). The haka was labelled as "demonical", "distorted", and "diabolical [in] appearance" (Polack, 1840, pp. 86-87), while the facial expressions were described as "'grotesque', 'savage', and 'indecent" (Kāretu, 1993, p. 29).

\section{Mãori as Physical-Unintelligent Other}

Māori were thought to be 'physical' and so 'unintelligent' (Hokowhitu, 2001). Physicality was linked to intelligence in a way that devalued Māori intelligence and knowledge, and this understanding was used to construct Māori as intellectually inferior (Hokowhitu, 2001). The inaccurate records and othering narratives of the 19th-century were influenced by Darwinian and other evolutionary ideologies (Hokowhitu, 2001; Simon, 1990; Wall, 1997). Pākehā judged Māori intelligence and knowledge through the lens of intellectual evolutionism: "a potent colonial ideology in Aotearoa, ratifying political inequalities and disclaiming Maori knowledge by a complete epistemological prejudgement" (Salmond, 1985, p. 
257). Indeed, as the demand for land grew, so did the popularity of Darwinian ideology (Salmond, 1985).

\section{Māori as Mythical Other}

The colonial assumption that Māori knowledge was inferior and mythical was linked to the idea that Māori lacked intelligence (Hokowhitu, 2001; Johnston, 2010). Māori knowledge-positioned in the pre-civilised past as myth, fable, and ancient tradition-was viewed, by Pākehā, as "primitive, pagan and inferior" (Hokowhitu, 2001; Raerino, 1999, p. 27; Smith, 2021).

Māori were thought to be incapable of making history since they were considered 'not fully human' (Smith 2021). Moreover, Hokowhitu (2001) suggested that writers in the 19th and early 20th centuries falsely classified Māori as uneducated because they believed Māori knowledge consisted solely of stories and myths.

\section{Mãori as Bewildered-Childlike Other}

Pākehā regarded Māori behaviour as antithetical to their own social mores, and as a result, Māori were portrayed as child-like, immature, and in need of civilisation; this representation of Māori was used to support colonisation (Hokowhitu, 2001). From this perspective, Māori, like other Polynesians, were considered "big, grown-up children" as Hall and Osborne (1901, cited in Tamplin 1992, p. 70) put it. 
Mãori as Romanticised-Noble Other

Smith (2021) asserted that the romanticisation of the South Pacific started with Rousseau, who imagined that the Indigenous peoples of the area were 'noble savages'. He believed they were noble because their relationships to nature reflected innocence and purity, qualities he claimed the West had lost (Smith, 2021). Furthermore, Rousseau believed that the Indigenous peoples of the Pacific held a moral superiority (Hokowhitu, 2001) that contrasted with the industrialised world's immorality (Smith, 2021). From this perspective, Māori were seen to be 'better blacks' than others since they were considered 'easier' to civilise (Belich, 2001).

\section{Māori and COVID-19}

COVID-19 has caused significant psychological distress (Shamblaw et al., 2021). However, Māori were quick to respond to COVID-19 through cultural adaption (McMeeking \& Savage, 2020). For example, adjusting tikanga such as hongi (Dawes et al., 2020; Pihama \& Lipsham, 2020; Rangiwai, 2020) and digitising karakia and tangihanga (Rangiwai \& Sciascia, 2021; Te One \& Clifford, 2021).

As Māori are a group vulnerable to COVID-19, it is crucial for Māori to follow public health advice (King et al., 2020; Rangiwai, 2021b). COVID-19 
conspiracy theories may prevent individuals from following public health advice (Rangiwai, 2021b). As Māori are already susceptible to conspiracy theories due to mistrust of institutions due to a history of colonial oppression (Rangiwai, 2021b), COVID-19 messaging must be designed to target Māori in culturally appropriate ways.

In a 24 July press release on social media, MP for Waiariki, Rawiri Waititi, stated the following:

As a person with a mataora, I think the use of it on a virus is completely inappropriate. A mataora is symbolic of life - tikanga, whakapapa, where you come from, and especially your tipuna. They are about peace, contribution, oranga and the revitalisation of our culture. The fact that the sacredness of mataora is being associated with a virus that is killing millions of people is an absolute disgrace.

Considering COVID-19 has the potential to take life, sums up its misuse in the manner in which it has been used. It is disappointing to see, however the concern is around the process in which this was allowed.

It has the potential to taint the art form and especially the symbolic meaning behind mataora and Ta Moko. To wear mataora is to be committed to Te Ao Maori. Viruses and disease like COVID-19, have no whakapapa and connection to us or mataora - so the depictions are completely wrong in the first place. 
We know that Māori are statistically more likely to be disproportionately affected by COVID-19. We also know that historically, the health system has failed Māori. Using symbolism from Te Ao Māori that puts mataora/tāmoko on a cartoon COVID-19 virus, is not only offensive, but could also potentially reinforce our people's distrust in the health system.

Whilst it is good that organisations are trying to embrace Te Ao Maori, this is a prime example of what happens when the correct processes aren't followed. This shouldn't be about blaming each other; it should be about looking at the process in which the graphics were approved.

This isn't just one agency involved, we're talking numerous agencies including Government departments who simply should know better.

I urge the parties involved to not throw each-other under the bus, but instead look to address what went wrong in terms of their internal process. This way all parties involved will follow proper process with correct tikanga that embraces Te Ao Māori in a respectful manner moving forward (Waititi, 2021, n.p.). 


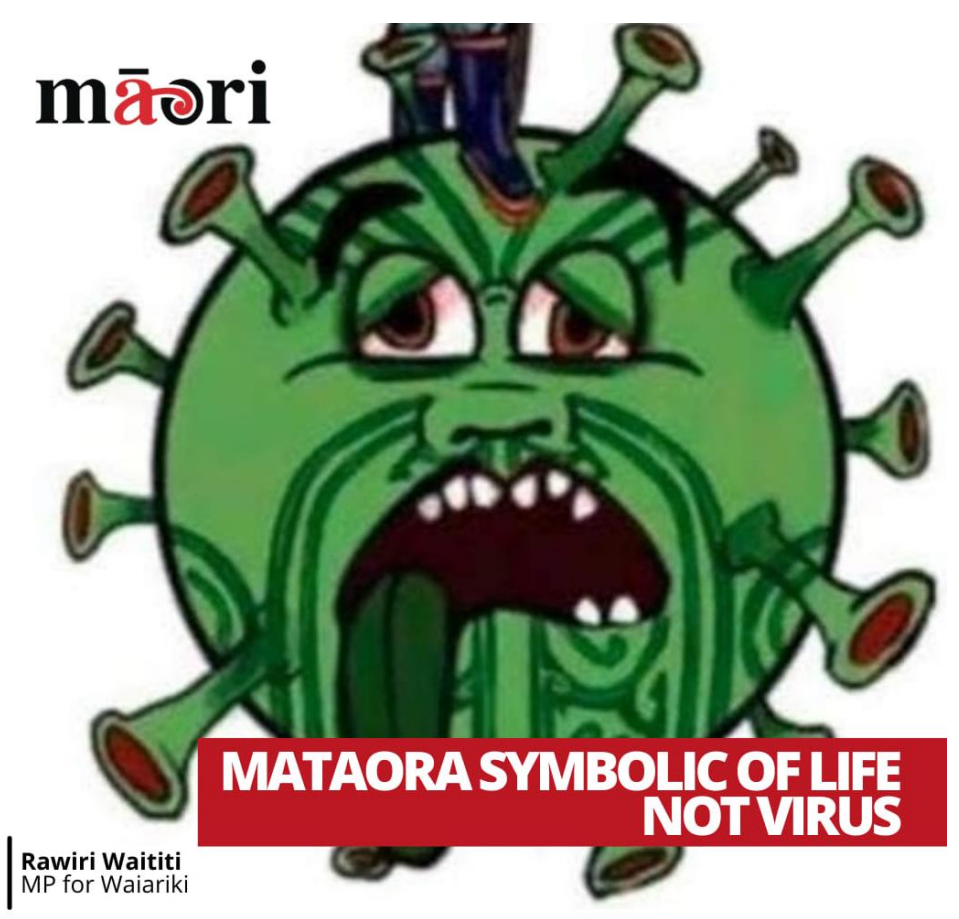

\section{(0) @MAORL_PARTY If MÃORIPARTY}

Figure 4. Māori Party social media image associated with 24 July media press release

\section{Mataora $=$ Māori: Representing Māori as COVID- 19 through the use of mataora}

Tâ moko is the art of scarification and pigmentation of the skin, distinctive to Māori, and related to the tatau of the Pacific (Te Awekotuku, 2006). Tā moko is central to Māori history and culture (Ellis, 2018) and "has always been a sophisticated and chiefly 
technology, and an arcane knowledge system" (Te Awekotuku, 2009, p. 5). From an oral history perspective, tā moko originated from the underworld through the story of Mataora and Niwareka (Ellis, 2018). From an archaeological standpoint, tā moko originated in the Pacific and evolved over the centuries from tatau-the practice of puncturing and pigmenting the skin-into a process of carving the skin (Ellis, 2018).

The narrative of Niwareka and Mataora recalls the origins of tā moko in the following way:

Niwareka lived in Rarohenga (the underworld). She chose to go to the world above, to Te Ao Marama (the world of light) to live amongst those tangata (human beings) who live in this world. In the world of light Niwareka partnered with Mataora. Mataora was abusive to her and in response Niwareka returned to Rarohenga to be amongst her people who did not agree to such behavior. Mataora followed Niwareka and after overcoming many trials and challenges he came across her father, Uetonga, who was a great carver of moko. Mataora wore the painted markings of the human world on his face, but in his encounter with Uetonga he was told that the markings of Rarohenga were permanent, and in time Uetonga began to place permanent moko on the face of Mataora. During that time Niwareka became aware of the presence of Mataora in the underworld and went to find him. Mataora spoke with Uetonga of his desire for Niwareka to return with him to the earthly world. Uetonga questioned the act of abuse, stating that, like temporary moko, 
that was not the way of their people. Mataora pleaded with Niwareka to return with him and, in doing so, agreed that by wearing the permanent moko of Uetonga he would take to his people both moko and the challenge to stop any abuse amongst his people. Niwareka agreed to return and she took the art form of taniko weaving back to the World of Light to share with the people above (Pihama \& Cameron, p. 225).

Jahnke (2010) stated that "The Mataora narrative sets up a series of interventions between two worlds, the material and the spiritual, and correspondingly between correct and incorrect knowledge, between permanent and impermanent designs, between old and young" (p. 128). According to te reo Māori and tikanga Māori expert Paraone Gloyne, Mataora was given the facial tā moko by Uetonga as a form of punishment for striking Niwareka (P. Gloyne, personal communication, July 23, 2021). Waitoki (2016) stated that even though the Mataora and Niwareka narrative is most often used to explain the origins of tā moko, it is also a story of conflict and healing. Mataora is also a word used to describe the male facial tâ moko; the facial markings used by the BOPDHB to adorn the COVID-19 virus.

Despite the effects of colonisation, which resulted in the decline of tā moko, the practice has now become a widespread method to express self-determination and cultural pride (Higgins, 2004). Contemporary tā moko, while still sacred and authentic, provides the 
means to unapologetically express Māori histories and identities on the skin and resist the impacts and effects of colonisation by promoting and elevating Māori cultural representations (Hart, 2019). As Te Awekotuku has argued, "By this active remembering in designs upon their skin, contemporary Maori assert a strong sense of identity, of survival and resilience, and by doing this, they also defy the colonial agenda. It is about being in the face of the other" (Te Awekotuku, 2009, p. 2). However, the BOPDHB's use of mataora to adorn COVID-19whether intentional or not-constructed Māori as the Other.

\section{Māori as Disease-Virus Other}

Extending Hokowhitu's (2001) work around the representation of Māori as Other, this paper argues that by conflating the virus with Māori through the symbolism of the mataora, the BOPDHB constructed Māori as disease-virus. There exists a long history of racialisation of disease concerning global pandemics (O’Neill, 2020). Indeed, marginalised people are often "scapegoated in times of crises and fear" (Tran, cited in O'Neill, 2020, n.p.). Unfortunately, as the rates of COVID-19 increased around the world, so too did reports of marginalised people experiencing discrimination and violence (Dionne \& Turkmen, 2020). Furthermore, diseases may be named for political reasons as a means of promoting fear of that which is considered foreign 
(Dionne \& Turkmen, 2020; O’Neill, 2020). For example, COVID-19 was labelled specifically by President Donald Trump as the "China virus" and "Kung Flu" (Dionne \& Turkmen, 2020).

It appears that the BOPDHB's portrayal of Māori as disease-virus is the first of its kind concerning Māori. However, there is much literature, historical material, and contemporary images relating to the dehumanising construction of Jewish people as lice, vermin, worms, and other disease-spreading creatures. In the image that follows-the front cover of a Community Security Trust publication-a montage of antisemitic images relating to COVID-19 is presented. At the centre, a familiar image of COVID-19 can be seen with the addition of an exaggerated 'Jewish nose'. This example bears some resemblance to the BOPDHB's image. 


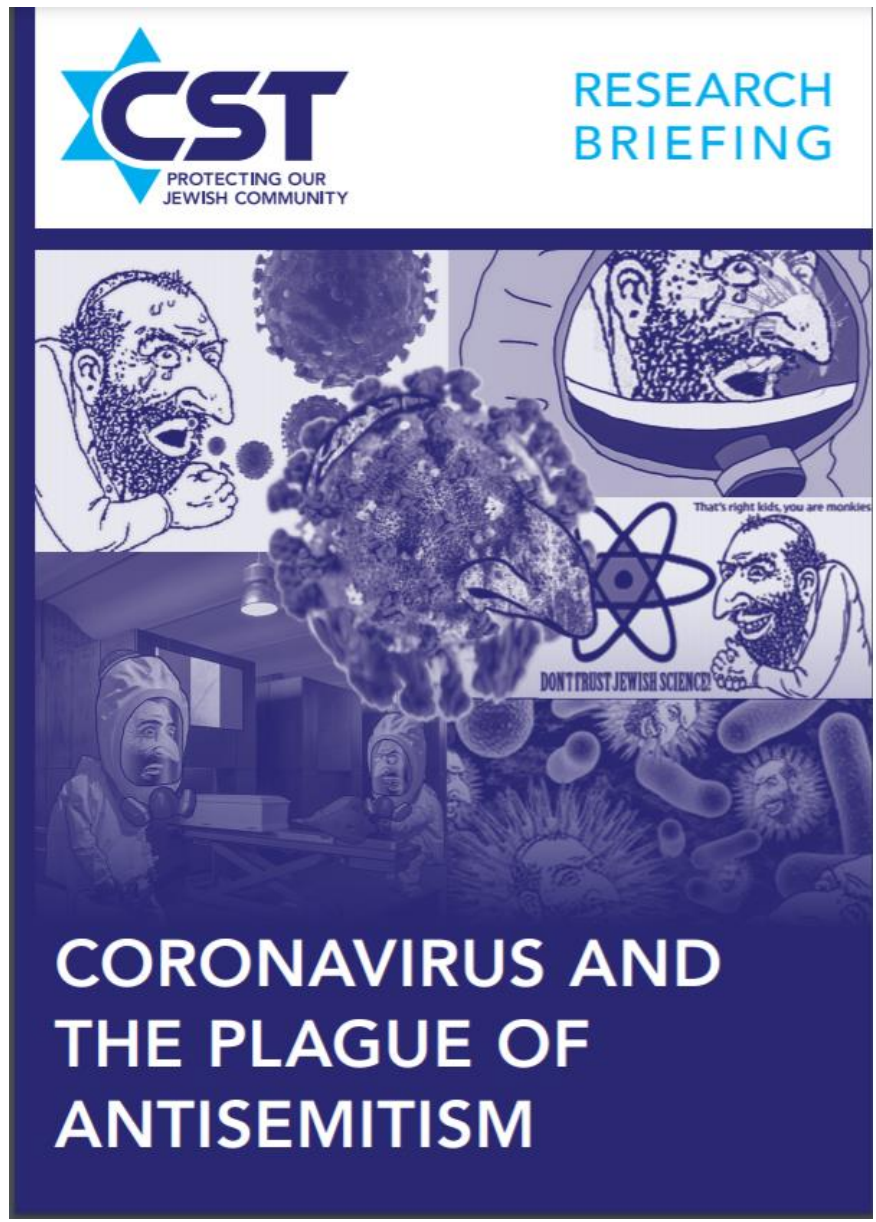

Figure 5. Front cover of a Community Security Trust publication (see https://cst.org.uk/)

\section{Taniwha as metaphor for COVID-19}

It would not have been the BOPDHB's explicit intention to portray Māori in a negative way as a disease or virus. However, based on anecdotal 
evidence, this is the way Māori observers have received the images. The only plausible conclusion about why the BOPDHB would represent COVID-19 as Māori is that they may have intended to use the concept of the taniwha as a metaphor for COVID-19. This metaphor would make sense. But, if this was the intention, the design language severely missed the mark.

As te reo Māori does not translate directly into English (Rangiwai, 2021a), definitions of the word taniwha are dependent on context. Some definitions of taniwha could be used metaphorically to describe COVID-19. However, as viruses do not fulfil the criteria of living beings (Farnsworth, 2021), this connection may not be precise in a literal sense.

Taniwha are understood to live in the environment and are described as monsters, water spirits, and dangerous or powerful creatures (Moorfield, 2011). Taniwha was also a word used to describe large lizards (Roberts, 2012). Taniwha took many forms, such as logs, reptiles or whales; some functioned as guardians, while others were sinister (Keane, 2011; Moorfield, 2011). Some taniwha offered protection, while others punished people for violating protocols (Moorfield, 2011; Simmons, 1986). Some taniwha, described as 'taniwha-logs' or 'demon-logs', were known to float upstream as warnings of impending war or death (Cowan, 1930). Taniwha may also be understood in anthropological (van Meijl, 2019) and psychological (Gemmell, 2020) terms as demons. 
Indeed, taniwha may be experienced by Māori in many ways and in many forms (Rangiwai, 2019).

For my grandmother, Repora Marion Brown (19402017), taniwha, kaitiaki or 'manas' as she sometimes called them, had the power to guide, guard, and protect, or to 'slap', if tikanga was not followed (Rangiwai, 2019). Thus, Nan's definition of taniwha aligns with Lythberg and Hikuroa's (2020) definition of taniwha as ancestral guardian and Sissons (2019) definition as ancestral embodiments. Taniwha have been used metaphorically-both positively and negatively-in a range of contemporary contexts including, leadership and performance (Ruwhiu, 2009), writing (Sword, 2011), design (Repia, 2018), law studies (Fernando, 2018), resistance to land loss and environmental degradation (van Meij1, 2019; McCormack, 2019; Sissons, 2019), digital leadership (Williams, 2020), and in many other contexts. The metaphor of the taniwha, van Meijl (2019) asserted, is important in Māori narratives as, "Spirituality and images of the taniwha are... central themes in Māori discourses" (p. 165).

\section{Conclusion}

The first argument in this paper claimed that the images in the BOPDHB's vaccine booklet were culturally inappropriate. From a Māori perspective, the images created meanings that extended racist 19th-century notions about Māori and have, 
probably quite inadvertently, mirrored the sentiments of antisemitic COVID-19 propaganda. By building on Hokowhitu's (2001) work, this paper argued that the BOPDHB constructed Māori as the disease-virus Other.

Hall (1973) contended that encoding and decoding is based on social and cultural norms. If the BOPDHB had intended to reach out to and communicate with Māori concerning COVID-19 vaccines, then surely the design language should come from a Māori worldview and be used in a culturally acceptable way. While mataora comes from a Māori worldview, the way in which it was used was inappropriate.

The second argument in this paper asserted that the BOPDHB may have intended to portray COVID in metaphorical terms as a taniwha. It was argued that there was potential for this metaphor to work but that if this had been the BOPDHB's intention, the design language failed to communicate this.

This example has demonstrated that the use of cultural images is fraught with difficulty. While it is important for communication with Māori to include cultural references, these must be used in culturally appropriate ways. 


\section{References}

Belich, J. (2001). Myth, race, and identity in New Zealand. In J. Binney (Ed.), The shaping of history: Essays from the New Zealand Journal of History (pp. 356-366). Bridget Williams Books.

Best, E. (1925). Tuhoe: Children of the mist. Reed.

Cowan, J. (1930). The Maori yesterday and to-day. Whitcombe \& Tombs.

Dawes, T., Muru-Lanning, M., Lapsley, H., Hopa, N., Dixon, N., Moore, C., Tukiri, C., Jones, N., MuruLanning, C., \& Oh, M. (2020). Hongi, harirū and hau: Kaumātua in the time of COVID-19. Journal of the Royal Society of New Zealand, 1-15. https://doi.org/10.1080/03036758.2020.1853182

Dionne, K. Y., \& Turkmen, F. F. (2020). The politics of pandemic othering: Putting COVID-19 in global and historical context. International Organization, 74(S1), E213-E230.

https://doi.org/10.1017/S0020818320000405

Ellis, N. (2018). Toitu te moko: Maintaining the integrity of the moko in the $19^{\text {th }}$ century and the work of Gottfried Lindauer. RIHA Journal, 0192. https://doi.org/10.11588/riha.2018.2.70265

Farnsworth, K. D. (2021). An organisational systemsbiology view of viruses explains why they are not alive. BioSystems, 200(104324), 1-14. https://doi.org/10.1016/j.biosystems.2020.10432 $\underline{4}$

Fernando, I. (2018). Taniwha in the room: Eradicating disparities for Māori in criminal justice - is the legal 
system up for the challenge? Canterbury Law Review, 24, 61-90. https://doi.org/10.3316/agispt.20190501009753

Gemmell, J. (2020). Kaupapa Mãori practitioner's whakaaro (thoughts) of traditional practices (rongoā, rāranga, mirimiri and pūrākau) assisting rangatahi Mãori (Mãori youth) with suicidal behaviours [Unpublished master's thesis, Massey University]. https://mrons.massey.ac.nz/handle/10179/16002

Giddens, A. (1993). Sociology (vol. 2). Blackwell. Hall, S. (1973). Encoding and decoding in the television discourse [Monograph, University of Birmingham]. Hall, S. (2001). Different: A historical context. Phaidon Press.

Hart, M. N. T. (2019). Tā moko: Marked histories and identities [Unpublished master's exegesis, Auckland University of Technology]. http://orapp.aut.ac.nz/handle/10292/13045

Higgins, R. R. (2004). He tānga ngutu, he Tūhoetanga: Te mana motuhake of te tā moko wāhine: The identity politics of moko kauae [Unpublished doctoral thesis, University of Otago]. https://ourarchive.otago.ac.nz/handle/10523/157 Hokowhitu, B. (2001). Te mana Mãori - te tātari i ngã kōrero parau [Unpublished doctoral thesis, University of Otago]. https://ourarchive.otago.ac.nz/handle/10523/133 
Hokowhitu, B. (2003). Race tactics: the racialised athletic body. Junctures, 1, 21-34.

Hokowhitu, B. (2004). Tackling Māori masculinity: A colonial genealogy of savagery and sport. The Contemporary Pacific, 16(2), 259-284.

Hook, G. R. (2009). "Warrior genes" and the disease of being Māori. MAI Review, 2, 1-11.

Jahnke, R. (2010). Ko Rūamoko e ngunguru nei: Reading between the lines. Journal of the Polynesian Society, 119(2), 111-130.

Johnston, P. M. (2010). Diversity, discrimination or difference: Case study Aotearoa/New Zealand. Indian Institute of Dalit Studies, Working Paper Series, 4(1), 1-32.

Käretu, T. (1993). Haka: The dance of a noble people. Reed.

Keane, B. (2011). Traditional Māori religion-ngā karakia a te Māori. Te Ara-Encyclopedia of New Zealand. https://teara.govt.nz/en/traditionalmaori-religion-nga-karakia-a-te-maori

King, P., Cormack, D., McLeod, M., Harris, R., \& Gurney, J. (2020, April 14). COVID-19 and Māori health-when equity is more than a word. Sciblogs. https://sciblogs.co.nz/public-healthexpert/2020/04/14/covid-19-and-maori-healthwhen-equity-is-more-than-a-word/

Lythberg, B., \& Hikuroa, D. (2020). How can we know Wai-Horotiu-A buried river? Cross-cultural ethics and civil art. Environmental Ethics, 42(4), 373-390. 


\section{https://doi.org/10.5840/enviroethics20204243} $\underline{4}$

McCormack, F. (2019). Comments. Current Anthropology, 60(2), 166-167.

\section{https://doi.org10.1086/702538}

McMeeking, S., \& Savage, C. (2020). Māori responses to Covid-19. Policy Quarterly, 16(3), 36-41.

McNaughton, T. O. P. (2004). Re-viewing identities: constructions of Māori in New Zealand children's picture books [Unpublished master's thesis, University of Auckland].

Moorfield, J. C. (2011). Te Aka-Māori-English, English-Māori dictionary. Pearson.

Nicole, R. (2001). The word, the pen, and the pistol: Literature and power in Tahiti. State University of New York Press.

Nikora, L. W., Rua. M., Te Awekotuku, N. (2007).

Renewal and resistance: Moko in contemporary New Zealand. Journal of Community \& Applied Psychology. https://doi.org/10.1002/casp.942

NZ Herald. (2021, July 23). 'Appalling' Bay of Plenty DHB vaccine booklet withdrawn, chair apologises. NZ Herald. https://www.nzherald.co.nz/nz/covid19-coronavirus-appalling-bay-of-plenty-dhb-

vaccine-booklet-withdrawn-chairapologises/M4I6MZWMFXC5XCM5NG4WKFGWYE $\perp$

O'Neill, C. (2020, September 3). The "Othering" of disease: Xenophobia during past pandemics. The Wiley

Network. 
https://www.wiley.com/network/featuredcontent/the-othering-of-disease-xenophobiaduring-past-pandemics

Petrie, H. (1998). The 'lazy Maori': Pakeha representations of a Maori work ethic 1890-1940 [Unpublished master's thesis, University of Auckland].

Pihama, L., \& Cameron, N. (2012). Kua Tupu Te Pā Harakeke: Developing Healthy Whānau Relationships. In Waziyatawin \& M. Yellow Bird (Eds.), For Indigenous minds only: A decolonization handbook (pp. 225-244). SAR Press.

Pihama, L., \& Lipsham, M. (2020). Noho haumaru: Reflecting on Māori approaches to staying safe during Covid-19 in Aotearao (New Zealand). Journal of Indigenous Social Development, 9(3), 92-101. https://ucalgary.ca/journals/jisd

Procter, J. (2004). Stuart Hall. Routledge.

Rangiwai, B. (2010). The effects of racism on Mãori land loss: Colonising discourses for Patuheuheu and Ngāti Haka [Unpublished master's thesis, Te Whare Wānanga o Awanuiārangiwai].

Rangiwai, B. (2011). 'Race' and the politics of land loss: Colonising discourses for Patuheuheu and Ngāti Haka. Te Kaharoa: The eJournal on Indigenous Pacific Issues, 4(1), 40-96. https://www.tekaharoa.com/index.php/tekaharoa /article/view/112

Rangiwai, B. (2019). A Kaupapa Māori study of the positive impacts of syncretism on the development of 
Christian faith among Mãori from my faith-world perspective [Unpublished doctoral thesis, University of

Otago].

https://ourarchive.otago.ac.nz/handle/10523/984 $\underline{7}$

Rangiwai, B. (2020). The impacts of COVID-19 on the hongi and the advent of the 'East Coast wave'. Te Kaharoa: The eJournal on Indigenous Pacific Issues, 15(1), $1-14$.

https://www.tekaharoa.com/index.php/tekaharoa Larticle/view/289

Rangiwai, B. (2021a). Hopo: The dread that clings. Te Kaharoa: The eJournal on Indigenous Pacific Issues, 17(1), 1-7.

https://www.tekaharoa.com/index.php/tekaharoa Larticle/view/361

Rangiwai, B. (2021b). "Wake up, sheeple!" Conspiracy theories and Māori during the COVID-19 pandemic. MAI Journal, 10(1), 46-49. https://doi.org/10.20507/MAIJournal.2021.10.1. $\underline{6}$

Rangiwai, B. W. \& Sciascia, A. D. (2021). The impacts of COVID-19 on tangihanga. Journal of Global Indigeneity, $5(1)$ $1-14$. https://www.journalofglobalindigeneity.com/articl e/19435-the-impacts-of-covid-19-on-tangihanga

Repia, H. (2018). Niho taniwha: Communicating tsunami risk: A site-specific case study for Tūranganui-a-Kiwa [Unpublished master's exegesis, 
Massey

University].

https://mro.massey.ac.nz/handle/10179/14752

Roberts, M. (2012). Mind maps of the Maori.

GeoJournal, 77(6), 741-751.

https://www.jstor.org/stable/23325384

Ruwhiu, D. (2009). The sleeping taniwha: Exploring the practical utility of Kaupapa Māori in firm performance [Unpublished doctoral thesis, University of Otago]. https://ourarchive.otago.ac.nz/handle/10523/580 Salmond, A. (1985). Maori epistemologies. In J. Overing (Ed.), Reason and morality (pp. 240-764). Routledge.

Shamblaw, A. L., Rumas, R. L., \& Best, M. W. (2021). Coping during the COVID-19 pandemic: Relations with mental health and quality of life. Canadian Psychology/Psychologie Canadienne, 1-9. https://doi.org/10.1037/cap0000263

Simmons, D. R. (1986). Iconography of New Zealand Maori religion. E. J. Brill.

Sissons, J. (2019). Comments. Current Anthropology, 60(2), 169-170. https://doi.org10.1086/702538 Smith, L. T. (1997). Maori women: Discourses, projects and mana wahine. In S. Middleton \& A. Jones (Eds.), Maori women and education 2 (pp. 33-51). Auckland University Press \& Bridget Williams Books.

Smith, L. T. (2021). Decolonizing methodologies:

Research and Indigenous peoples. Zed.

Sword, H. (2011). Thinking outside the box. MAI Review, 2, Writing Workshop 11. 
http://www.review.mai.ac.nz/mrindex/TK/article/ download/460/460-3319-1-PB.pdf

Tamplin, R. (1992). Noble men and noble savages. In M. Gidley (Ed.), Representing others: white views of Indigenous peoples (pp. 60-83). University of Exeter Press.

Te Awekotuku, N. (2006). Mata Ora: Chiseling the living face - dimensions of Maori tattoo. In E. Edwards, C. Gosden \& R. B. Phillips (Eds.), Sensible objects (pp. 121-140). Routledge.

Te Awekotuku, N. (2009). Memento Mori: Memento Maori-moko and memory. Tangi Research Programme Working Paper. Hamilton, New Zealand: Maori and Psychology Research Unit, University of Waikato.

https://researchcommons.waikato.ac.nz/handle/1 $\underline{0289 / 3486}$

Te One, A., \& Clifford, C. (2021). Tino rangatiratanga and wellbeing: Māori self determination in the face of Covid-19. Frontiers in Sociology, 6(613340), 1-10. https://doi.org/10.3389/fsoc.2021.613340

van Meijl, T. (2019). Doing indigenous epistemology: Internal debates about inside knowledge in Māori society. Current Anthropology, 60(2), 155-166. https://doi.org10.1086/702538

Wade, W. (1977). A journey in the northern island of New Zealand. Capper Press.

Waititi, R. (2021, July 24). \#MediaRelease MP for Waiariki and co-leader of Te Paati Māori, Rawiri Waititi - says the process that has seen the Bay of 
Plenty District Health Board communications botch, should be the focus of investigation [Facebook update].

https://www.facebook.com/RawiriWaititiMP/

Waitoki, W. (2016). The baskets of knowledge: A curriculum for an indigenous psychology. In W. Waitoki \& M. Levy (Eds.), Te Manu Kai $i$ Te Mãtauranga: Indigenous Psychology in Aotearoa/New Zealand (pp. 283-299). The New Zealand Psychological Society.

Wall, M. (1997). Stereotypical constructions of the Maori 'race' in the media. New Zealand Geographer, 53(2), 40-45.

Williams, W. (2020). Digital taniwha: Growing Māori participation in the IT industry [Unpublished doctoral thesis, University of Waikato]. https://researchcommons.waikato.ac.nz/handle/1 $\underline{0289 / 13842}$

Wilson, L., \& Bathgate, B. (2021, July 23). Māori artist created offensive pamphlet design with moko on cartoon virus. Stuff. https://www.stuff.co.nz/poutiaki/125840147/covid19-mori-artist-createdoffensive-pamphlet-design-with-moko-on-cartoonvirus 